\title{
A NOTE ON UNION-NON-UNION BENEFIT DIFFERENTIALS AND SIZE OF ESTABLISHMENT
}

\author{
Donald G. BRAMLEY and Phanindra V. WUNNAVA \\ Middlebury College, Middlebury, VT 05753, USA \\ Michael D. ROBINSON \\ Mt. Holyoke College, South Hadley, MA 01075, USA
}

Received 25 October 1988

Accepted 8 January 1989

This research note has expanded Podgursky's (1986) results concerning union-non-union differentials to benefits. Explicitly, union impacts on pension and health insurance coverage are obtained by plant size. Our empirical results are based on May 1983 CPS data of random sample of white males. They indicate that the pattern of differentials for health insurance are very similar to those obtained by Podgursky (i.e., the union-non-union differentials are largest in small plants). However, the results for pension coverage indicate a U-shaped union-non-union differential (i.e., the smallest and largest plants are found to have the largest differential).

\section{Introduction}

While there has been a great deal of research on the effects of firm size on earnings [Lester (1967), Masters (1969), Mellow (1982), Dunn (1986)], only Podgursky (1986) investigated the impact of firm size on union-non-union wage differentials. Podgursky has shown empirically that union-non-union wage differentials are largest in small plants. This paper extends Podgursky's results to other forms of compensation. Union impacts on health insurance and pension coverage are obtained by plant size. At least three theories can be put forward that suggest that the impacts of union activity as measured by union-non-union wage or benefit differentials will be larger in small firms: union threat effects, efficiency wages, and the wage dispersion effects of unions.

After a discussion of the theoretical issues, this paper presents evidence from 1983 CPS data that suggests that union-non-union benefit differentials do not differ across firm sizes as much as wage differentials. Results for pension coverage indicate that there are large union-non-union differences in pension coverage even in largest plants. However the results of health care coverage conform to the pattern observed by Podgursky.

\section{Union-non-union wage / benefit differentials across firm sizes}

In this section three theoretical perspectives are presented to support the argument that the union-non-union wage/benefit differential may vary with firm size. First we consider union threat 
effects, then efficiency wages and wage dispersion (even though we made our arguments in terms of 'wages' one could also apply them to 'benefits'). The first reason that large firms may offer higher wages than small firms is union threat effects. The large non-unionized firm may pay higher wages to decrease the threat of unionization. Large non-unionized firms realize they are the best union targets and therefore raise wages to maintain worker satisfaction and discourage the entrance of unions. A large firm is a better target for unionization than a small firm, since the large firm provides a larger worker pool than a small firm. A larger worker pool allows more workers to be solicited into entering the union and thus the costs of unionizing a large firm are less than those of unionizing a small firm.

The distinct difference in union-non-union wage differentials between small and large firms is partially attributable to the large firm paying higher wages than the small firm. The large firm pays significantly higher wages than the small firm due to efficiency wage theory and union threat effects. Also, it appears as if there is a maximum wage for a particular job. In large non-unionized firms this wage is usually close to the maximum, while in small non-unionized firms the wage is far below the maximum. The large firm which becomes unionized only can obtain a small wage increase so that the maximum is not surpassed. However, the small firm that becomes unionized is able to obtain a much greater increase in wages without reaching the maximum wage. The factors that cause the large firms to have higher wages than small firms are the factors which are responsible for the greater union-non-union wage differentials in the small firms than in the large firms.

First, efficiency wage theory states that large firms pay higher wages so that monitoring costs ${ }^{1}$ are minimized as incentives are maximized. The efficiency wage theory is based on the belief that monitoring costs increase as firms increase in sizc. As more cmployecs are hired the hicrarchy of the firm becomes more complex and the cost of supervising the employees increases. The management of a large firm must hire supervisors to monitor its workers which is unnecessary in a small firm. In a small firm the president or even owner can notice when an employee is not fulfilling his job requirements. By offering higher wages the large firm increases the worker's job value; the opportunity cost of the job is increased. When worker job value increases the worker will be more conscientious, responsible and dependable. The large firm pays higher wages to limit monitoring costs and to develop a better work force. The efficiency wages are not necessary in the small firm because in a small firm monitoring costs are small.

It is clear that we expect union-non-union compensation differentials to be larger in small plants. However, it is not clear whether these effects will be confined solely to wage compensation or will be observable for benefits as well. In part union strategies may dictate how union-non-union differentials will be distributed between wages and benefits. If union strategies differ across plant sizes the pattern of differentials may vary as well.

\section{Data and methodology}

The estimations were performed using a random sample from the May 1983 Current Population Survey. The sample included only white male-full-time workers for the non-agriculture and non-public sector. The dependent variables $\left(P_{i}\right)$ are dummy variables indicating either participation in the pension plan or participation in a health insurance plan at work. Human capital variables are included in the model along with industrial, regional and occupational controls. Following is our

\footnotetext{
${ }^{1}$ Polachek and Curtis (1988) showed that once the monitoring costs are integrated into a worker-firm bargaining model, there exists an inverse relationship between rates of unionization and costs of monitoring workers.
} 
empirical specification:

$$
\begin{aligned}
P_{i}= & \alpha+\beta_{1}(\text { Education })_{i}+\beta_{2}(\text { Age })_{i}+\beta_{3}\left(\text { Age }^{2}\right)_{i}+\beta_{4}(\text { Tenure })_{i}+\beta_{5}\left(\text { Tenure }^{2}\right)_{i} \\
& +\beta_{6}(\text { Union Status })_{i}+(\text { Vector of Regional Dummies }) \mu+(\text { Vector of Industrial Dummies }) \eta \\
& +(\text { Vector of Occupational Dummies }) \omega+\text { Error }_{i} .
\end{aligned}
$$

This model was estimated for four different size firms: 0-24 employees, 25-99 employees, 100-499 employees, and $500+$ employees.

\section{Results and conclusions}

The logistic regression results ${ }^{2}$ of eq. (1) are presented in tables 1 (pension plan) and 2 (health plan). For pension coverage, the union-non-union differentials follow a U-shaped pattern. The smallest and the largest firms are found to experience the largest differential (in fact the largest differential is found in the largest plant). The other variables perform as expected. Education, tenure and age all increase the worker's probability of being included in the pension plan.

Table 1

Union effects on pension participation by plant size-logistic regression estimates.

Dependent variable: 1 for workers in pension plans, 0 otherwise.

\begin{tabular}{lcccc}
\hline Independent variables & \multicolumn{2}{l}{ Firm size: number of employees } & & \\
\cline { 2 - 4 } & $0-24$ & $25-99$ & 0.171 & $500+$ \\
\hline Union & $1.779^{* *}$ & $1.144 * *$ & $(0.38)$ & $(0.53)$ \\
Tenure & $(0.30)$ & $(0.32)$ & $0.126 * *$ & $0.169^{* *}$ \\
& $0.103^{* *}$ & $0.167 * *$ & $(0.06)$ & $(0.08)$ \\
Tenure & $(0.03)$ & $(0.04)$ & -0.086 & -0.178 \\
& -0.147 & $-0.274 * *$ & $(0.26)$ & $(0.25)$ \\
Age & $(0.12)$ & $(0.131)$ & 0.006 & $0.589 * *$ \\
& $0.267^{* *}$ & $0.266 * *$ & $(0.10)$ & $-0.006 * *$ \\
Age & $(0.062)$ & $(0.068)$ & -0.0003 & $(0.001)$ \\
& $-0.003 * *$ & $-0.003 * *$ & $(0.001)$ & 0.032 \\
Education & $(0.0007)$ & $(0.0008)$ & 0.0758 & $(0.085)$ \\
Intercept & $0.173 * *$ & 0.004 & $(0.069)$ & $-14.7 * *$ \\
& $(0.05)$ & $(0.06)$ & -3.33 & $(3.32)$ \\
Sample size & $-9.51^{* *}$ & $-5.85 * *$ & $(2.22)$ & 337.0 \\
- 2 log-likelihood & $(1.44)$ & $(1.63)$ & 334.0 & 190.63 \\
\hline
\end{tabular}

** Significant at the 95 percent level. Standard errors are in parentheses.

2 To conserve space, we did not report the parameter estimates of regional, industrial, and occupational dummies. They can be obtained from the authors upon request. 
Table 2

Union effects on health plan participation by plant size-logistic regression estimates.

Dependent variable: 1 for workers with health plan, 0 otherwise

\begin{tabular}{|c|c|c|c|c|}
\hline \multirow[t]{2}{*}{ Independent variables } & \multicolumn{4}{|c|}{ Firm size: number of employees } \\
\hline & $0-24$ & $25-99$ & $100-499$ & $500+$ \\
\hline Union & $\begin{array}{l}1.199 * * \\
(0.37)\end{array}$ & $\begin{array}{l}1.678 * * \\
(0.55)\end{array}$ & $\begin{array}{c}0.936 \\
(0.69)\end{array}$ & $\begin{array}{c}0.105 \\
(0.90)\end{array}$ \\
\hline Tenure & $\begin{array}{l}0.115 * * \\
(0.044)\end{array}$ & $\begin{array}{l}0.192 * * \\
(0.063)\end{array}$ & $\begin{array}{c}0.044 \\
(0.11)\end{array}$ & $\begin{array}{c}0.221 \\
(0.156)\end{array}$ \\
\hline Tenure $^{2}$ & $\begin{array}{c}-0.190 \\
(0.159)\end{array}$ & $\begin{array}{c}-0.449^{* *} \\
(0.17)\end{array}$ & $\begin{array}{c}-0.21 \\
(0.38)\end{array}$ & $\begin{array}{c}0.247 \\
(0.417)\end{array}$ \\
\hline Age & $\begin{array}{l}0.149 * * \\
(0.047)\end{array}$ & $\begin{array}{l}0.242 * * \\
(0.074)\end{array}$ & $\begin{array}{l}0.396 * * \\
(0.152)\end{array}$ & $\begin{array}{l}0.546 * * \\
(0.21)\end{array}$ \\
\hline $\mathrm{Age}^{2}$ & $\begin{array}{r}-0.057 \\
(0.05)\end{array}$ & $\begin{array}{c}-0.03 \\
(0.08)\end{array}$ & $\begin{array}{r}-0.042 \\
(0.184)\end{array}$ & $\begin{array}{r}0.065 \\
(0.25)\end{array}$ \\
\hline Education & $\begin{array}{l}0.259^{* *} \\
(0.054)\end{array}$ & $\begin{array}{c}0.128 \\
(0.093)\end{array}$ & $\begin{array}{c}0.089 \\
(0.123)\end{array}$ & $\begin{array}{c}0.169 \\
(0.203)\end{array}$ \\
\hline Intercept & $\begin{array}{c}-6.60 * * \\
(1.19)\end{array}$ & $\begin{array}{c}-6.49 * * \\
(1.91)\end{array}$ & $\begin{array}{l}6.58 * * \\
(3.28)\end{array}$ & $\begin{array}{c}6.27 \\
(4.64)\end{array}$ \\
\hline Sample size & 586.0 & 408.0 & 334.0 & 337.0 \\
\hline 2 log-likelihood & 557.0 & 269.09 & 121.23 & 73.21 \\
\hline
\end{tabular}

** Significant at the $95 \%$ level. Standard errors are in parentheses.

The results for health insurance coverage are much the same as Podgursky's wage results. Large and significant union-non-union differentials are found only at plants with less than 100 workers. Against the remaining variables have the expected signs.

This research note has expanded Podgursky's 1986 results concerning union-non-union differentials to benefits. The pattern of differentials for health insurance matches that for wage differentials. However, the results for pension coverage does not indicate the pattern. This may indicate that unions in large plants are more concerned with pension benefits than other forms of compensation.

\section{References}

Ackerloff, George A., 1984, Gift exchange and efficiency wages: Four views, American Economic Review 74, May, $200-208$. Bramley, Donald G., 1988, The effects of firm size and unions on employee earnings and benefits: A total compensation analysis, Honors thesis (Middlebury College, Middlehury, VT).

Dunn, L.F., 1986, Work disutility and compensating differentials: Estimation of factors in the link between wages and firm size, Review of Economics and Statistics 68, Feb., 67-73.

Lester, Richard, 1967, Pay differentials by size of establishment, Industrial Relations 7, Oct., 57-67.

Masters, Stanley, H., 1969, An interindustry analysis of wages and plant size, Review of Economics and Statistics 51, Aug., 341-345.

Mellow, Wesley, 1982, Employer size and wages, Review of Economics and Statistics 64, Aug., 341-345.

Podgursky, Michael, 1986, Unions, establishment size, and intra-industry threat effects, Industrial and Labor Relations Review 39, Jan., 277-284.

Polachek, Solomon W., and Curtis J. Simon, 1988, Monitoring and the rate of unionization, Working paper no. 43, Jan. (Trade Union Institute for Economic Research, Stockholm). 